\title{
laborhiftórico
}

ISSN 2359-6910

https://revistas.ufrj.br/index.php/lh/

ARTIGO

Recebido em 5 de junho de 2020

Aprovado em 16 de agosto de 2020

\section{Campo lexical do curandeirismo em inquéritos policiais do século XIX}

Lexical field of healing in police inquiries of the $19^{\text {th }}$ century

DOI: https://doi.org/10.24206/lh.v6i3.35305

Renata Ferreira Costa

Professora Adjunta do Departamento de Letras Vernáculas, do Programa de Mestrado Profissional em Letras e do Programa de Pós-Graduação em Ciência da Informação da Universidade Federal de Sergipe. Mestre e Doutora em Letras, área de concentração Filologia e Língua Portuguesa, pela Universidade de São Paulo. Líder do Grupo de Estudos Filológicos em Sergipe - GEFES/ CNPq.

E-mail: renataferreiracosta@yahoo.com.br ORCID: https://orcid.org/0000-0002-4263-4955

Larissa Pinbeiro Santos

Graduada em Letras pela UFS. Membro do Grupo de Estudos Filológicos em Sergipe - GEFES/CNPq.

E-mail: larissapinheiro98@hotmail.com ORCID: https://orcid.org/0000-0002-2878-3786 
Letícia Santos

Graduada em Letras pela UFS. Membro do Grupo de Estudos Filológicos em Sergipe - GEFES/CNPq.

E-mail: leticia.saantos_@hotmail.com

ORCID: https://orcid.org/0000-0002-7510-7879 


\section{RESUMO}

Partindo da teoria dos campos lexicais proposta por Eugenio Coseriu, apresentam-se aqui os resultados de uma pesquisa desenvolvida em um corpus específico: inquéritos policiais produzidos em Sergipe, nas últimas décadas do século XIX, que registram crimes motivados pelo exercício de práticas místico-religiosas de cura. Através da investigação do universo lexical dos documentos, objetivou-se entender, em primeiro plano, no que consistia e como era realizada a atividade do curandeiro, e, secundariamente, identificar as imagens e representações dessa prática, as relações de poder e a presença de aspectos do discurso civilizador que vigorava no período, especialmente no que concerne à preocupação com a saúde pública. $\mathrm{O}$ trabalho segue os pressupostos teórico-metodológicos da Filologia, em seu labor de edição de textos, da Lexicologia, com ênfase na teoria dos campos lexicais, e dos Estudos da História Sociocultural sobre o curandeirismo no Brasil. A estruturação do campo lexical do curandeirismo e suas respectivas subdivisões, que agrupam as lexias presentes nos inquéritos investigados, representativas das práticas e saberes tradicionais de cura, possibilitou uma reflexão sobre uma parcela da história cultural do século XIX, ajudando a entender a criminalização do curandeirismo e o preconceito e perseguição ainda vigentes às pessoas que se dedicam a essa prática.

Palavras-chave: Filologia. Lexicologia. Campos lexicais. Curandeirismo. Inquérito policial.

\section{ABSTRACT}

Starting from the theory of lexical fields proposed by Eugenio Coseriu, the results of a research developed in a specific corpus are presented here: police inquiries produced in Sergipe, in the last decades of the $19^{\text {th }}$ century, which register crimes motivated by the exercise of mystical-religious practices of cure. Through the investigation of the lexical universe of documents, the goal was to understand, first, what it was and how the healer's activity was carried out, secondarily, to identify the images and representations of this practice, the power relations and the presence of aspects of the civilizing discourse that prevailed in the period, especially about public health concerns. The work follows the theoretical-methodological assumptions of Philology, in its text editing work, of Lexicology, with an emphasis on the theory of lexical fields, and the Studies of Sociocultural History on healing in Brazil. The structuring of the lexical field of healing and its respective subdivisions, which group the lexias present in the investigated inquiries, representative of traditional healing practices and knowledge, made it possible a reflection on a part of the $19^{\text {th }}$ century cultural history, helping to understand the criminalization of healing and the prejudice and persecution still in force for people who dedicate themselves to this practice.

Keywords: Philology. Lexicology. Lexical fields. Healing. Police inquiries. 


\section{Introdução}

A documentação escrita remanescente depositada em arquivos públicos é fonte primária necessária e indispensável para a investigação do universo histórico e cultural de uma sociedade e a única forma de se testemunhar um fato linguístico do passado, uma vez que, segundo Havelock (1996, p. 14), “a linguagem oral não produz fósseis".

Diante da diversidade de tipos de textos que se encontram à disposição dos pesquisadores, tem se destacado o uso de registros judiciais como fontes para a análise histórica e linguística, porque, além de registrarem as vozes de pessoas comuns, como observa Burke (2010, p. 27), fornecem dados a respeito do perfil das personagens envolvidas na ação judicial, dos seus modos de vida e dos conflitos que vivenciaram.

Nesses documentos, as palavras dispostas sobre o papel, já desgastado pela ação do tempo e do manuseio constante, carregam as marcas culturais de um indivíduo e do grupo social do qual faz parte, na medida em que o seu repertório lexical, arcabouço de significados, é a via de acesso aos seus valores, experiências, costumes, hábitos e crenças, enfim, à sua visão de mundo.

Nesse sentido, tomando o texto escrito como testemunha de uma realidade histórica, sociocultural e linguística, este trabalho propõe uma investigação do universo lexical de inquéritos policiais escritos em Sergipe, nas últimas décadas do século XIX, que registram crimes motivados pelo exercício de práticas místico-religiosas de cura.

Apresentam-se neste artigo os resultados da pesquisa intitulada Edição Filológica e Estudo Léxico Semântico de Processos Criminais de Curandeirismo, desenvolvida no âmbito do Grupo de Estudos Filológicos em Sergipe (GEFES-CNPq) ${ }^{1}$, com o apoio do Programa Institucional de Bolsas de Iniciação Científica (PIBIC 2018-2019). Objetivou-se entender, em primeiro plano, no que consistia e como era realizada a atividade do curandeiro, e, secundariamente, identificar as imagens e representações dessa prática, as relações de poder e a presença de aspectos do discurso civilizador que vigorava no período, especialmente no que concerne à preocupação com a saúde pública.

Tomou-se a Filologia como ciência atuante a embasar o método de leitura, transcrição e descrição dos manuscritos que compõem o corpus. São dois inquéritos policiais sob a guarda do Arquivo Judiciário de Sergipe, produzidos na cidade de Maruim, em 1889 e 1897, os quais foram editados semidiplomaticamente de acordo com normas específicas para a conservação do estado de língua dos textos.

\footnotetext{
${ }^{1}$ Espelho do grupo disponível em: http://dgp.cnpq.br/dgp/espelhogrupo/370590.
} 
Ademais, de modo a compreender a correlação entre fatores linguísticos e sociais, realizou-se o levantamento de informações sobre o contexto histórico em que os documentos foram produzidos, bem como sobre a legislação em vigor no período e os motivos para a criminalização do curandeirismo. Essa abordagem histórica ganha bastante relevância ao se considerar, como apontam Marcotulio et al. (2018, p. 14), que "a conjugação da descrição de fenômenos históricos e linguísticos à análise de textos remanescentes tem sido pouco explorada".

Finalmente, procedeu-se à identificação das lexias designativas de práticas de cura, as quais foram classificadas em campos lexicais referentes ao universo do curandeirismo, conforme os princípios da teoria dos campos lexicais proposta por Eugenio Coseriu, com vistas a evidenciar "as relações internas do campo léxico enquanto estrutura de conteúdo" (COSERIU, 1977, p. 213). Além disso, propôs-se um mapa conceitual que desse conta de representar graficamente a interligação dos itens lexicais em seus respectivos campos, num mesmo quadro de significação.

\section{O discurso médico-higienista e o desprezo pelas práticas populares de cura}

O período monárquico brasileiro termina em 15 de novembro de 1889, quando se promulga a Primeira República, também conhecida como República Velha (1889-1930), cujos ideais fundamentam-se nos pressupostos do Positivismo, fundado por Auguste Comte (1798-1857), na França, na segunda metade do século XIX. Essa corrente filosófica exaltava a ciência como a única forma de se alcançar o conhecimento verdadeiro, como guia da vida individual e coletiva, em oposição à metafísica e ao mundo espiritual. Assim, dispensavam-se as explicações sobrenaturais ou teológicas para os fenômenos da vida, que deveriam ser comprovados através de técnicas científicas, para o desenvolvimento da humanidade. Comte foi, segundo Lins (1964, p. 522), "o primeiro a observar que a objetividade do conhecimento sem a qual não há verdade, nem ciência, se acha no caráter coletivo do conhecimento, em seu valor impessoal, logo social”.

No Brasil, a filosofia positivista contribuiu para nortear a nova ordem social republicana, influenciando na criação do lema "Ordem e Progresso" inscrito na bandeira nacional, de acordo com o qual o progresso de uma nação está diretamente relacionado ao respeito à ordem. Dessa forma, tudo que fugisse desse padrão cientificista era tido como atrasado, bárbaro e, portanto, maléfico à sociedade.

Em meio ao desenvolvimento das ciências, ganha bastante destaque, no século XIX e primeiras décadas do século XX, um novo ramo da medicina, o higienismo, que, no Brasil, foi impulsionado pelo processo de transformação política e econômica pelo qual passava a sociedade oitocentista, principalmente por conta da abertura do comércio internacional, da imigração e do aumento 
populacional. Vale lembrar que a chegada da família real, em 1808, permitiu o estabelecimento de ações modernizadoras e civilizatórias na provinciana sociedade colonial, nos moldes europeus, com a finalidade de restabelecer a ordem.

Conforme o higienismo, os problemas na organização social e no funcionamento das cidades contribuíam para a falta de higiene da população, que causava, por sua vez, o aumento de doenças, de modo que, como observam Mansanera e Silva (2000, p. 118), os governos republicanos passaram a se preocupar com "o desenvolvimento de um projeto de controle higiênico dos portos, a proteção da sanidade da força de trabalho e o encaminhamento de uma política demográfico-sanitária que contemplasse a questão racial”. A esse respeito, Costa $(2013$, p. 67$)$ salienta que

O discurso higienista define a organização do espaço urbano, interfere nas políticas de urbanização das cidades européias e é utilizado para justificar grandes intervenções urbanas. Com o retorno das teorias hipocráticas, domina a concepção geográfica/ecológica, em que a doença é localizada no meio ambiente, ou seja, na água, na terra e no ar, três elementos indispensáveis da natureza, mas que se tornam inimigos em potencial.

Nesse cenário, inaugura-se um espaço de valorização do conhecimento científico dos médicos, que desenvolviam argumentos e ações para tratar as doenças comuns da época, como a febre amarela e a tuberculose, mas perceberam que fatores de cunho social deveriam ser levados em consideração no tratamento. Para esses profissionais, os espaços urbanos deveriam estar adequados para dar assistência à sociedade, sendo necessária uma fiscalização em relação à educação infantil, aos cuidados com a higiene e cuidados sanitários e, inclusive, em relação ao comportamento social. Esse discurso está presente em teses defendidas em faculdades de medicina do Brasil desde 1840, que indicavam desde exercícios físicos para melhorar a saúde até o modo como as salas de aula deveriam estar dispostas (GONDRA, 2004). Segundo Jacó-Vilela et al. (2004, p. 142), essas teses se situam na esfera da Medicina Social, defendendo "que a sociedade fosse organizada e livre de desvios. O que causava ‘desordem' deveria ser eliminado ou devidamente controlado através de projetos profiláticos e reparadores".

Verifica-se que o discurso médico-higienista está contido em um programa civilizador, o qual induziu a uniformização dos comportamentos humanos, colocando-os num modelo comum de conduta, que, nos trópicos, como observa Gondra (2004, p. 22), instituiu "uma réplica complexa do que então era considerado como padrão civilizatório a ser disseminado, imposto e adotado no mundo ocidental”.

Norbert Elias explica melhor esse processo em O Processo Civilizador: uma História dos Costumes (1935) e Processo Civilizador: Formação do Estado e Civilização (1939). O autor afirma que essa 
intervenção civilizatória pode ser notada no modo de falar das pessoas, na forma como sentavam-se à mesa, no modelo familiar, etc. Todos esses fatores fortaleceram ainda mais as relações de poder. A elite operava sobre as classes baixas e estas tinham que deixar de lado seus costumes identitários, reinventando uma espécie de segunda natureza. Elias (1994, p. 128) observa que "as pessoas, no curso do processo civilizatório, procuram suprimir em si mesmas todas as características que julgam ‘animais".

Embora a medicina tenha sido institucionalizada como prática terapêutica oficial no Brasil somente em 1832, com a fundação das faculdades de medicina da Bahia e do Rio de Janeiro, as curas por meio de práticas ou crendices populares realizadas por benzedores, barbeiros-sangradores, curandeiros, feiticeiros, boticários, etc. continuavam a ser exercidas. Assim, os "médicos diplomados" tinham que conviver com as práticas de cura místico-religiosas, de caráter popular e de maior prestígio entre a população desde os tempos coloniais.

As ações terapêuticas da medicina acadêmica, embasadas no discurso higienista, eram muito similares às práticas populares de cura, uma vez que o conhecimento científico a respeito da saúde ainda era bastante limitado. No entanto, havia uma grande resistência das camadas populares em aceitar as práticas científicas, por diversos fatores, mas principalmente pela associação que faziam entre religião, doença e cura, de modo que "a escolha dos curandeiros era feita a partir de um referencial de concepções religiosas consideradas legítimas pela população que recorria aos seus serviços de cura" (ALMEIDA, 2008, p. 4).

A existência de diferentes práticas curativas, que se opunham em sua maneira de significar a saúde, acabou gerando conflitos sociais e resistência cultural, como observa Almeida (2008, p. 8). O discurso médico-científico, visando sua institucionalização e o monopólio do ofício de curar, buscou, então, impor-se frente às formas terapêuticas populares, desautorizando-as e desqualificando-as como charlatanismo e exercício ilegal da medicina.

Consequentemente, os praticantes do curandeirismo, cujas raízes se encontram na fusão de tradições indígenas, africanas e europeias (cristãs), sofriam com a perseguição dos médicos diplomados e da classe dominante, uma vez que suas ações envolviam a cura de alguém por meio da administração de substâncias, gestos ou palavras, recorrendo a forças ocultas, num processo que se pode chamar místico-religioso. Tudo que fugisse, então, da conduta social e dos valores culturais e religiosos dominantes, sofria perseguição e era colocado à margem da sociedade. Um exemplo dessa discussão está presente no livro O Poder dos Candomblés (2009), em que Edmar Ferreira Santos apresenta uma análise histórica, antropológica e discursiva da perseguição que as religiões de matriz africana sofreram na cidade de Cachoeira, na Bahia, nas primeiras décadas do século XX, como ficou registrado especialmente no jornal cachoeirense "A Ordem", o que retrata bem a ideologia civilizatória que se disseminava pelo Brasil desde o século anterior. 
Os grupos dominantes, especialmente a imprensa local, empreenderam uma dura campanha de perseguição aos adeptos do candomblé, classificando os serviços religiosos e terapêuticos de mães e pais-de-santo como curandeirismo ou feitiçaria e hostilizando-os "em razão da terapêutica por eles utilizada no atendimento e cura dos mais diversos problemas físicos e materiais. Essa terapêutica era frequentemente identificada com feitiçarias e torturas que levavam pessoas ignorantes à morte" (SANTOS, 2009, p. 31).

A recriminação às práticas de cura místico-religiosas, especialmente as relacionadas às religiões afro-brasileiras, configura-se como um mecanismo de controle republicano, amparado no discurso civilizador, que remete à ordem pública, à higiene e, como salienta Santos (2009, p. 57), à "proteção da família, da sociedade e da raça”.

Assim, apesar de haver liberdade religiosa desde a Constituição de 1891, o discurso das classes dominantes e da legislação brasileira apoia-se na ideia de cura por meio de saberes mágicos, denominados como sinônimos de "feitiçaria", "bruxaria”, "magia negra”, "curandeirismo", "macumba", "ocultismo" e "espiritismo", como algo não civilizado, que remete à recordação de um passado recente de escravidão e de uma herança de religiões originárias da África, o que se desejava esquecer.

A desqualificação da medicina popular se dá principalmente por meio de sua associação à superstição, à feitiçaria, à magia negra, ao culto ao demônio, logo, à irracionalidade, à barbárie, à incivilidade. A esse respeito, quando aborda o discurso da imprensa da cidade baiana de Cachoeira contra os praticantes de candomblé, Santos $(2009$, p. 84) aponta que

[...] fica clara a intenção dos jornalistas de desacreditar processos terapêuticos alternativos praticados por mulheres e homens que, aos olhos de alguns setores letrados, eram desqualificados. No estágio de civilização em que presumiam estar, a única Medicina admitida era a dos doutores. Esta era apoiada pela lei e por setores da imprensa que a julgavam científica e tentavam estabelecê-la como a única possível.

O Código Criminal do Império de 1830 não versava sobre o exercício da medicina popular, mesmo porque a medicina científica ainda não havia sido oficializada. Contudo, a perseguição aos curandeiros encontrava respaldo no Código Penal de 1890, que, em seus artigos 156, 157, 158 e 159, como forma de manutenção da ordem pública e social, criminalizava as práticas de cura místicoreligiosas, especialmente as provenientes de crenças minoritárias, como as de matriz africana, contra a saúde pública, uma vez que, para o Estado, representavam condutas antissociais, em desacordo ao projeto republicano de modernização, higienização e saneamento urbano.

O artigo 156 versava sobre o exercício ilegal da medicina "em qualquer dos seus ramos, a arte dentaria ou a pharmacia" e "a homeopatia, a dosimetria, o hypnotismo ou magnetismo animal"; o 
artigo 157 referia-se a quem praticasse "o espiritismo, a magia e seus sortilegios", usasse "de talismans e cartomancias para despertar sentimentos de odio ou amor", inculcasse "cura de molestias curaveis ou incuraveis, emfim, para fascinar e subjugar a credulidade publica"; no artigo 158, enquadrava-se todo aquele que ministrasse, ou simplesmente prescrevesse, "como meio curativo para uso interno ou externo, e sob qualquer fórma preparada, substancia de qualquer dos reinos da natureza, fazendo, ou exercendo assim, o officio do denominado curandeiro"; o artigo 159 indicava penalidades a quem expusesse à venda ou ministrasse "substancias venenosas, sem legitima autorização e sem as formalidades prescriptas nos regulamentos sanitarios".

Em 1940, um novo Código Penal entra em vigor, ainda em vigência, que segue criminalizando as práticas de cura populares como exercício ilegal da medicina - Art. 284, seguindo com a perseguição, repressão e condenação penal de homens e mulheres que, em contraponto ao saber médico científico, oferecem a cura de enfermidades por intermédio de elementos da natureza e da fé.

Para uma melhor compreensão do corpus deste trabalho e do exame dos usos e sentidos das palavras que aparecem nos textos selecionados, foi de extrema importância estudar o contexto sociohistórico e cultural de sua produção, para que se pudesse entender como esses discursos modeladores e um certo "dispositivo de exclusão de saberes anônimos e populares", como quer Gondra (2004, p. 31), estavam presentes, ainda que de maneira implícita, nos inquéritos policiais relativos à prática do curandeirismo produzidos em Sergipe no final do século XIX.

Esse tipo de atividade terapêutica, apesar de bastante comum no Brasil desde o período colonial, passou a ser fortemente depreciada e perseguida por não se enquadrar nos preceitos moralizantes e civilizatórios, importados da Europa, das sociedades oitocentista e novecentista, visto que envolviam a cura de alguém por meios ditos irracionais.

\section{Língua, Cultura, Léxico e Teoria dos Campos Lexicais}

Segundo Benveniste (1991, p. 288), é através da linguagem que o homem se constitui como sujeito, por isso, forma e sentido devem estar alinhados. Nessa visão pós-estruturalista, a língua é muito mais que "un conjunto de categorías fonológicas, morfológicas, sintácticas o léxicas y una serie de reglas para su uso" (DURANTI, 2000, p. 104), desprovida da realidade social de seus falantes, é uma forma de comunicação que veicula normas, comportamentos, valores e experiências individuais e coletivas, conforme um contexto temporal e espacial específico. 
Nesse sentido, a língua registra, expressa e dá acesso à realidade cultural de uma dada sociedade, é a mais forte representação da cultura, ou, como salienta Câmara Jr. (1955, p. 53), "é uma parte da cultura, mas uma parte que se destaca do todo e com ele se conjuga dicotomicamente". Essa convergência entre língua e cultura se manifesta principalmente através do léxico, que consiste em um conjunto de unidades significativas que tem função referencial e é compartilhado pelos usuários de uma língua, revelando suas formas de ser, agir, pensar e dizer.

O léxico é um inventário aberto e dinâmico, resultado, conforme Biderman (1978, p. 139), da tensão entre o indivíduo e a sociedade, e, por isso, se situa entre o significado linguístico e o contexto extralinguístico. É através do léxico que o ser humano, em interação com outros sujeitos, demonstra seus interesses, sentimentos, crenças e ideias, porque as palavras carregam as marcas sociais e culturais de quem as enuncia. Assim, como destaca Seabra (2015, p. 73, grifos da autora),

[...] podemos ver, no léxico, o patrimônio cultural de uma comunidade. Transmitidos de geração a geração como signos operacionais, é através dos nomes que o homem exerce a sua capacidade de exprimir sentimentos e ideias, de cristalizar conceitos. Assim, o patrimônio lexical de uma língua constitui um arquivo que armazena e acumula as aquisições culturais representativas de uma sociedade, refletindo percepções e experiências multisseculares de um povo, podendo, por isso, ser considerado testemunho de uma época, [...]

Nesse sentido, o léxico de uma língua, enquanto "testemunho de uma época", abre possibilidades para o resgate e a compreensão da história cultural de uma determinada comunidade. Para isso, há uma série de ciências que tem o léxico como objeto de estudo, a exemplo da Lexicologia, da Lexicografia, da Terminologia e da Onomástica, cada uma com objetivos específicos. Dentre elas, a Lexicologia é a mais ampla, dedicando-se à investigação das unidades significativas de uma língua em sua forma (plano da expressão) e em seu significado (plano do conteúdo), o que correspondente a "duas subdivisões: a morfologia, estudo das formas das palavras e dos seus componentes, e a semântica, estudo dos seus significados" (ULLMANN, 1964, p. 64).

Ao considerar a dimensão significativa do léxico, a Lexicologia faz fronteira com a Semântica em um ramo denominado Lexemática, ou Semântica Estrutural, que, em uma determinada língua, se ocupa das palavras lexicais, ou lexias, que possuem significação lexical (correspondente a referências extralinguísticas e uso social), excluindo-se outros tipos de significação e também, segundo Abbade (2012, p. 146), palavras como "interjeições; partículas de afirmação ou negação; palavras morfemáticas como artigos, preposições; categoremas como pronomes, assim como os nomes próprios e os numerais”, que não manifestam configuração semântica. Assim, segundo Coseriu (1987, p. 229), 
La tarea fundamental de la lexemática en cuanto disciplina estructural descriptiva consiste en deslindar dentro de las lenguas funcionales y describir de manera sistemática y exhaustiva la paradigmática y sintagmática del vocabulario en el plano del contenido. Su especificidad frente al estudio funcional de las lenguas en general de lo específico de las estructuras paradigmáticas y sintagmáticas que considera.

A partir da Semântica Estrutural, Eugenio Coseriu desenvolveu a teoria dos campos lexicais, influenciada pelos estudos dos campos linguísticos de Jost Trier. De acordo com esses estudos, as palavras não se encontram na mente dos falantes de forma isolada, mas organizadas em conjuntos estruturados e articulados, pertencentes à mesma esfera conceitual, originando um campo linguístico formado através de um campo conceitual específico. O campo lexical, por sua vez, resulta do agrupamento de itens lexicais que compartilham o mesmo sentido, numa

[...] relação de coordenação e hierarquia entre as palavras que são organizadas à maneira de um mosaico: o campo léxico. Nesse sentido, as palavras que ocupam determinado campo estão individualmente determinando seus significados pelo número e pela situação. As palavras estão organizadas em um campo com mútua dependência, ou seja, elas adquirem uma determinação conceitual a partir da estrutura do todo. $\mathrm{O}$ significado de cada palavra vai depender do significado de suas vizinhas conceituais. As palavras só têm sentido como parte de um todo, pois só no campo terão significação. (ABBADE, 2012, p. 151, grifos da autora).

A teoria dos campos lexicais formulada por Coseriu propõe, então, uma análise estrutural das lexias, estabelecendo sua organização em um grupo ou campo baseado em relações paradigmáticas de semelhança, nos quais os lexemas apresentam entre si oposições semânticas mínimas, em função de sua realidade extralinguística:

El campo léxico es una estructura paradigmática primaria del léxico; más aún: es, en este dominio, la estructura paradigmática por excelencia. Puede definirse como paradigma constituido por unidades léxicas de contenido ("lexemas") que se reparten una zona de significación continua común y se encuentran en oposición inmediata unas con otras. (COSERIU, 1977, p. 210).

Os campos lexicais articulam-se hierarquicamente, de modo que, segundo Teixeira (2015, p. 67), possuem "subdivisões de subconjuntos variados, conforme a natureza e especificidades dos dados trabalhados". Assim, Coseriu apresenta uma segmentação dos campos em macro e microcampos, considerando "o macrocampo como um campo superior com totalidade articulada, composto por uma soma de lexias organizadas que farão parte de campos inferiores, os microcampos", como declara Abbade (2012, p. 152). 
Partindo da teoria dos campos lexicais coseriana, apresentam-se aqui os resultados de uma pesquisa desenvolvida em um corpus específico: inquéritos policiais oitocentistas, que registram crimes motivados pelo exercício de práticas místico-religiosas de cura.

Através da investigação do universo lexical dos documentos, a finalidade do estudo foi entender, em primeiro plano, no que consistia e como era realizada a atividade do curandeiro, e, secundariamente, identificar as imagens e representações dessa prática, as relações de poder e a presença de aspectos do discurso civilizador que vigorava no período, especialmente no que concerne à preocupação com a saúde pública.

A estruturação do campo lexical do curandeirismo e suas respectivas subdivisões, que agrupam as lexias presentes nos inquéritos investigados, representativas das práticas e saberes populares de cura, contribuirá para uma reflexão sobre uma parcela da história cultural do século XIX, ajudando a entender a criminalização das práticas de cura místico-religiosas no Brasil e o preconceito e perseguição ainda vigentes às pessoas que se dedicam a essas práticas.

\section{Apresentação do corpus e sua edição}

Abrangendo estudos de crítica textual, edição de textos e história da língua, a Filologia Portuguesa vem ganhando espaço no cenário brasileiro, sob iniciativa de grupos de pesquisa e de universidades públicas, um vez que, como observam Cambraia e Megale (1999, p. 4), "alega-se que a descrição da língua esbarra na ausência de documentação cuja lição confiável só a Filologia pode apresentar".

A partir de meados de 1980, a retomada do interesse pelos estudos linguísticos diacrônicos, especialmente no que concerne à história do português do Brasil (cf. Megale e Cambraia, 1999), resultou na intensificação da investigação do "estado sincrônico de um passado remoto" em textos antigos, segundo Kato (1996, p. 16), porque são esses documentos os únicos testemunhos sobre a história da língua, visto que não é possível ao pesquisador contar com a competência do falante:

Não dispomos do "falante nativo" para julgamentos de agramaticalidade/ gramaticalidade, aceitabilidade/ não-aceitabilidade. Será a recorrência de fatos linguísticos nos dados dos documentos o indicador para nos tirar desses dilemas. (MATTOS E SILVA, 2002, p. 455)

Ressalta-se, deste modo, a relevância do aporte filológico de edição de textos a fundamentar os estudos diacrônicos do português, na medida em que facilita o acesso às fontes históricas, que 
documentam as diversas fases da história da língua, e fornece ao pesquisador edições rigorosas e fidedignas.

Desta forma, levando em consideração a importância da recuperação e estudo filológico e linguístico de textos de sincronias passadas, este artigo, a partir dos pressupostos teóricometodológicos da Filologia e da Lexicologia, volta-se para o labor investigativo de reconstrução da história linguística brasileira, tendo como objetivo a edição e análise linguística, com foco nas lexias do universo do curandeirismo como prática terapêutica e como crime contra a saúde pública, de dois inquéritos policiais ${ }^{2}$ das últimas décadas do século XIX, coletados no Arquivo Geral do Judiciário de Sergipe.

É importante destacar que o inquérito policial, "denominado dessa maneira desde 1871" (GRINBERG, 2009, p. 122), não é um processo criminal, mas um procedimento preparatório e preventivo de caráter administrativo e inquisitivo, preliminar à ação penal. Segundo Romano (2020, p. 3), sua finalidade é "a investigação do crime e a descoberta do seu autor, com o azo de fornecer ao autor da ação penal elementos sobre o caso”. Por ser peça preparatória, o inquérito possui características próprias, que o diferenciam do processo penal, como pode ser observado no quadro a seguir:

Quadro 1 - Características do Inquérito Policial em comparação com o Processo Penal.

\begin{tabular}{|l|l|l|}
\cline { 2 - 3 } \multicolumn{1}{c|}{} & \multicolumn{1}{c|}{ Inquérito Policial } & \multicolumn{1}{c|}{ Processo Penal } \\
\hline É uma fase... & Inquisitória (Policial) & Processual (Judicial) \\
\hline São produzidos... & $\begin{array}{l}\text { Elementos Informativos (não } \\
\text { precisam de contraditório e } \\
\text { ampla defesa) }\end{array}$ & $\begin{array}{l}\text { Provas (precisam de contraditório } \\
\text { e ampla defesa) }\end{array}$ \\
\hline Com o objetivo de formar... & $\begin{array}{l}\text { A “opinio delictis” (convicção do } \\
\text { acusador) } \\
\text { Que resultará em... }\end{array}$ & $\begin{array}{l}\text { Obertura ou arquivamento do convencimento do julgador } \\
\text { (juiz ou júri) }\end{array}$ \\
\hline processo Condenação ou absolvição \\
\hline
\end{tabular}

Fonte: Adaptado de Faria (2016).

Os inquéritos policiais editados foram produzidos na cidade de Maruim, no Estado de Sergipe, e informam as circunstâncias de crimes que têm como pano de fundo práticas místico-religiosas de cura, de modo que se reconhece que o curandeirismo não foi a motivação real para a configuração do

\footnotetext{
${ }^{2}$ Destaca-se que, como registrado no Guia de Fontes Temáticas do Arquivo (SILVA, 2009), haveria em seu acervo seis processos-crime relativos, direta ou indiretamente, ao curandeirismo. No entanto, a pesquisa na instituição permitiu identificar apenas dois documentos, os quais são aqui analisados.
} 
crime, mas as consequências advindas dessa terapêutica. Ainda assim, vislumbra-se no inquérito de 1897 a consecução de dois crimes, o de atentar contra a vida de outra pessoa e o exercício ilegal da medicina, conforme o Código Penal de 1890.

O documento datado de 20 de abril de 1889, escrito pelo escrivão Benvindo Francisco do Lago, relata os crimes de lesão corporal e homicídio cometidos por curandeiros contra duas pessoas. Consta nos autos que uma das vítimas, uma mulher chamada Maria, ficou bastante doente, com gastroenterite aguda, depois de beber uma substância corrosiva contida em uma garrafa fornecida pelo curandeiro Balbino. A outra vítima, um rapaz chamado Antônio, por estar adoentado de um catarro e sofrer de fraqueza nas pernas, foi-lhe informado que sua enfermidade era "malefício"/ "feitiçaria", no que recorreu ao curandeiro Barnabé, sócio de Balbino, que lhe ministrou duas garrafas com beberagens, as quais fizeram seu estado piorar, até vir a óbito.

Como é possível observar pela descrição acima, e muito mais detidamente a partir da leitura da edição semidiplomática desse documento, Balbino assumia diferentes funções no contexto de seu poder sobrenatural: curar doenças, físicas ou espirituais, curar feitiços, mas também promover feitiços, nos moldes do que Laura de Mello e Souza (2009, p. 225) identificou em sua pesquisa.

Interessante notar no auto a presença de um médico, que teria apreendido substâncias tóxicas de uma das vítimas do curandeiro Balbino, o que acaba por "concretizar ideologicamente o poder médico, profissional lícito e fora de qualquer cogitação criminosa” (PUTTINI, 2011, p. 46), em oposição às práticas e saberes populares de cura enquanto ações ilícitas relativas à saúde pública.

Destaca-se também nesse inquérito a prescrição de "garrafas de beberagens", também denominadas "garrafadas", uma espécie de medicamento, "uma fórmula medicinal preparada com componentes de origem vegetal, mineral e animal, complementada com elementos religiosos próprios dos sistemas de crenças vigentes no Brasil”, como define Camargo (2011 apud PASSOS et al., 2018, p. 249). Essas substâncias, que costumavam combinar plantas medicinais e bebidas alcóolicas, sempre associadas ao elemento religioso/ espiritual, eram (e ainda são) bastante difundidas entre as camadas populares para a cura de diversas enfermidades.

Atualmente,

É possível encontrar as garrafadas disponíveis para a venda em feiras livres e mercados populares em várias regiões do Brasil. [...] Nesses locais, esses produtos, preparados e mantidos por grupos culturais, como raizeiros, rezadores, curandeiros e vendedores de plantas medicinais, são vendidos livremente. (PASSOS et al., 2018, p. 249-250).

No contexto do inquérito, é mencionada primeiramente a ação corrosiva das substâncias contidas na garrafa, o que causou, ou teria agravado, a gastroenterite aguda da vítima; na segunda vez 
em que a garrafada é mencionada, são fornecidos os seus componentes: aguardente do reino, casca de jurema, alho e fumo, e descrito o seu aspecto: "beberagem branca e água adocicada com gosto amargo", o que especifica a sua administração por via oral.

Ainda nesse documento, chama a atenção os relatos fantásticos de algumas testemunhas, que afirmam terem presenciado ou ouvido dizer que a vítima Antônio, cuja enfermidade era proveniente de um feitiço, depois de ingerir as beberagens, passou a "vomitar sapo e cabellos pela boca", "vomitar uma cobra" e "lançar pequenos molhos de cabellos, retalhos de chita e palha de impalhar cadeira e pedra pelos ouvidos". A esse respeito, Souza (2009, p. 230) observa que "um número considerável de feitiços destinados a provocar malefícios e desgraças era feito com cabelos", assim, era natural "que o enfeitiçado expelisse cabelos quando o contrafeitiço era adequadamente encaminhado". Esse tipo de relato reforça ainda mais o caráter sobrenatural do curandeirismo:

Procurar obter curas por meios sobrenaturais aproximava pois esta terapêutica popular da feitiçaria. Curavam-se doenças, insolações, incômodos como dores de dentes; mas também se curavam feitiços. [...] o curandeiro tinha função paradoxal: identificado ao feiticeiro, era freqüentemente chamado para desfazer feitiços. (SOUZA, 2009, p. 224).

No inquérito datado de 23 de junho de 1897, também escrito por Benvindo Francisco do Lago, o fato criminoso envolveu uma tentativa de cura, que resultou em lesão corporal. Consta que o acusado Antônio, de passagem por Maruim para fazer mesas e negócios de feitiçaria, foi requisitado pela vítima, chamada Angelina, para curá-la de uma asma, mas acabou queimando sua roupa e partes de seu corpo ao embeber um pouco de algodão com aguardente, pôr fogo e aplicá-lo sobre um pequeno corte que fizera no peito da vítima.

Esse documento apresenta os procedimentos de cura utilizados por Antônio, que se valiam de elementos da natureza, como é comum no curandeirismo, e também uma intervenção no corpo da vítima, um corte, ação que adentra o espaço legítimo de atuação da medicina oficial.

As fontes documentais analisadas permitiram identificar alguns aspectos sociais dos sujeitos envolvidos, direta ou indiretamente, no ato criminoso relatado: não há referência a uma religião específica, mas há indícios de que as práticas de cura estavam associadas a um saber tradicional ou a religiões afro-brasileiras (garrafas de beberagens, casca de jurema, fumo, batuque do cemitério, mesas, negócios de feitiçarias); os acusados, as vítimas e as testemunhas são homens e mulheres pobres, que não sabem ler e escrever; os dois curandeiros são do gênero masculino e não há identificação de sua raça, mas, como afirma Souza (2009, p. 222), "africanos, índios e mestiços foram os grandes curandeiros do Brasil colonial. O conhecimento que tinham das ervas e de procedimentos rituais específicos a seu universo cultural atrelou-se ao acervo europeu da medicina popular". 
Os documentos referidos são manuscritos originais, que foram editados semidiplomaticamente segundo as "Normas para transcrição de documentos manuscritos para a História do Português do Brasil”, que constam em Megale e Toledo Neto (2005, p. 145-148).

Esse tipo de edição apresenta uma reprodução tipográfica do texto, com algumas intervenções medianas do editor, como o desenvolvimento de abreviaturas, procurando conservar o mais fielmente possível o estado de língua do texto original, o que demanda, conforme Fachin (2008, p. 19), "conhecimentos filológicos e critérios rigorosos".

À guisa de exemplo, seguem abaixo as edições semidiplomáticas, acompanhadas dos fac-símiles dos manuscritos originais, dos primeiros fólios dos inquéritos de 1889 e 1897:

Figura 1 - Edição semidiplomática fac-similar do inquérito policial de 20 de abril de 1889.

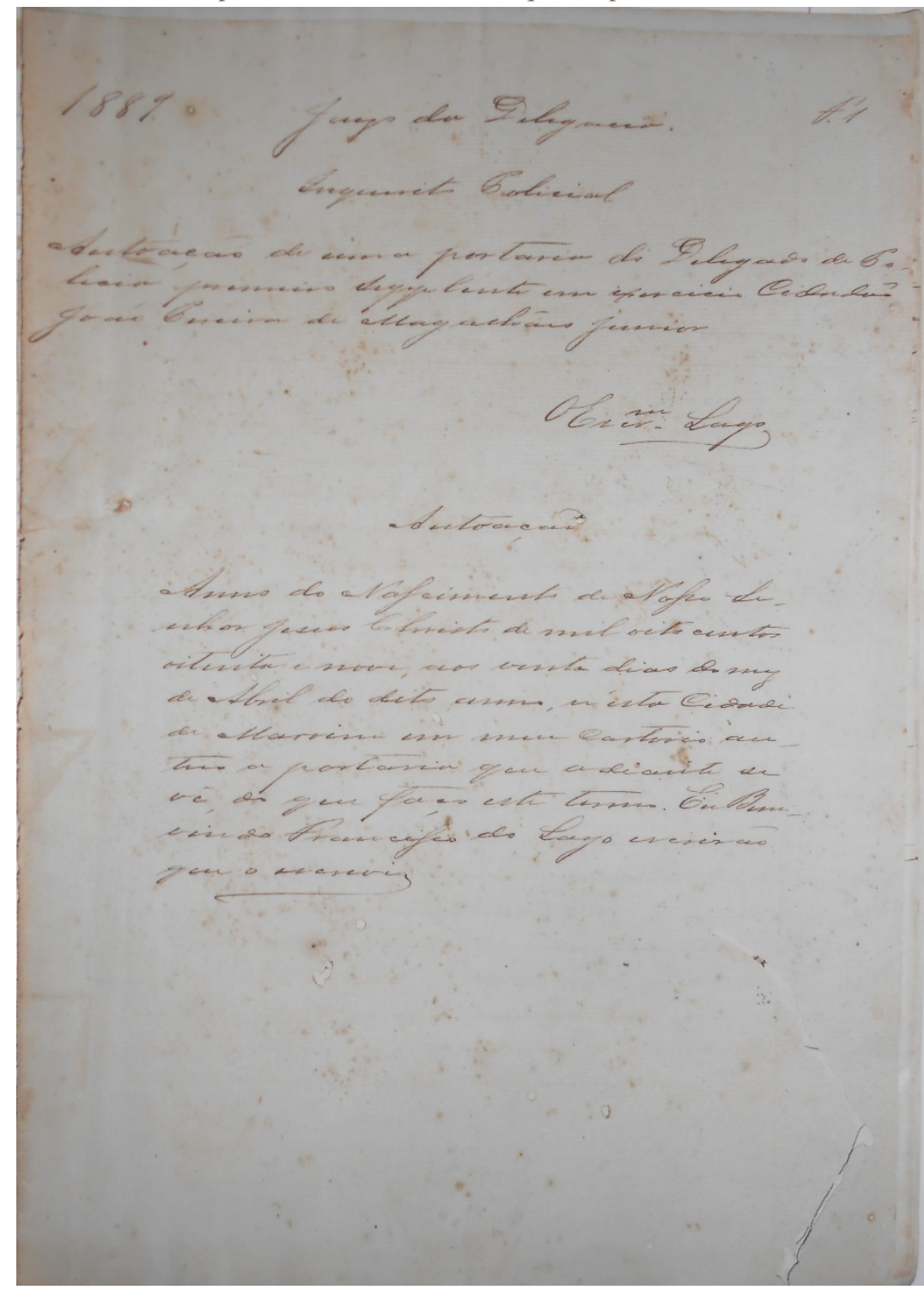


Juizo da Delegacia.

Inquerito Policial

Autoaçaõ de uma portaria do Delegado de Policia primeiro Supplente em exercicio Cidadaõ

5 Joaõ Pereira de Magalhães Junior

\section{OEscrivam Lago}

Autoaçaõ

Anno do Nascimento de Nosso Senhor Jesus Christo de mil oito centos

10 oitenta e nove, aos vinte dias do mez de Abril do dito anno, n'esta Cidade de Maroim em meu Cartorio autuo a portaria que adiante se vê, do que faço este termo. Eu Bem-

15 vindo Francisco do Lago escrivã̃ que o escrevi.

Figura 2 - Edição semidiplomática fac-similar do inquérito policial de 23 de junho de 1897.

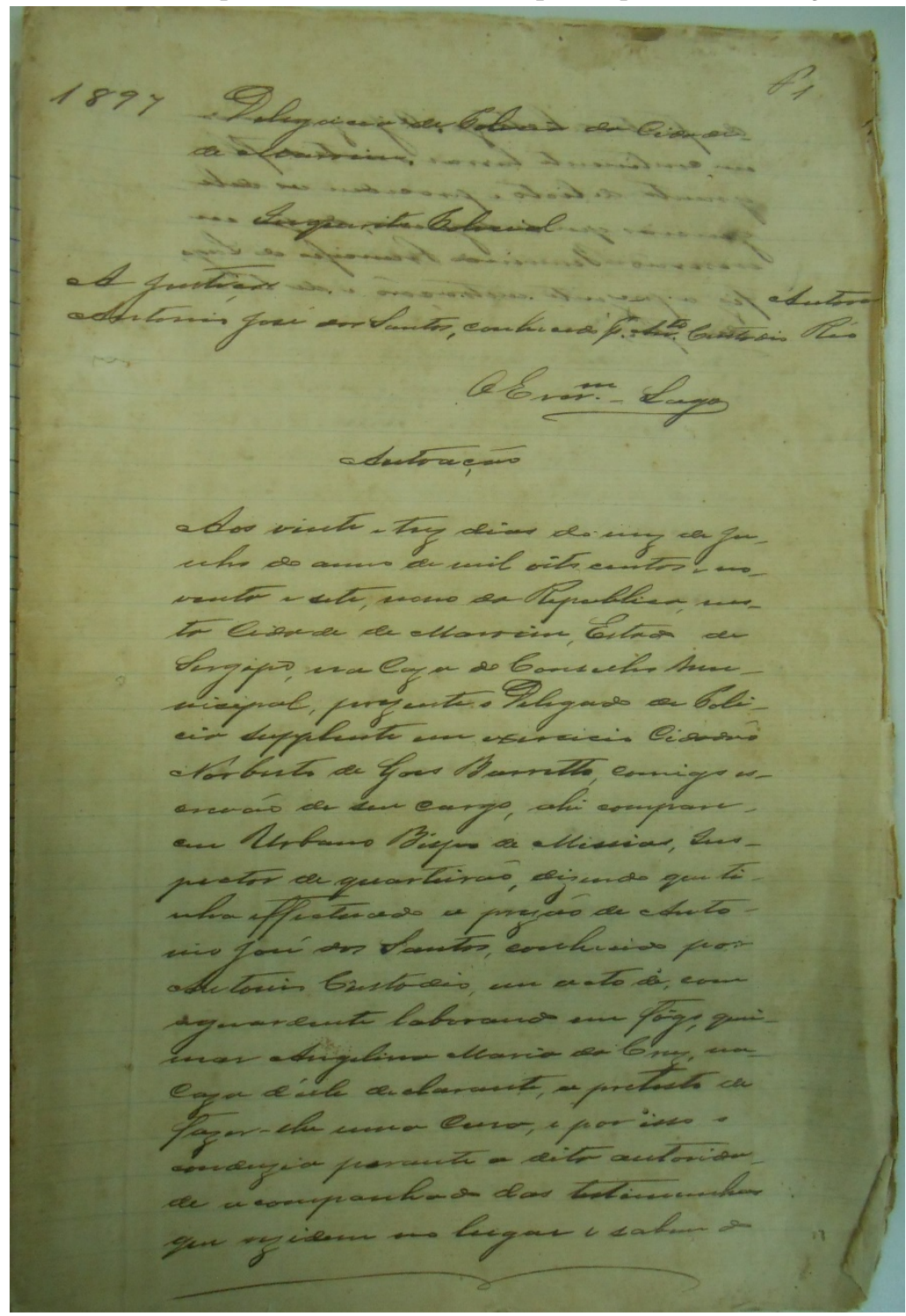


1897 Delegacia de Policia da Cidade de Maroim.

Inquerito Policial

A Justiça [espaço] Autoou

5 Antonio José dos Santos, conhecido por Antonio Custodio Réo

OEscrivam Lago

Autoação

Aos vinte e trez dias do mez de Junho do anno de mil oito centos e no-

10 venta e sete, anno da Republica, nesta Cidade de Maroim, Estado de Sergipe, na Caza do Conselho Municipal, prezente o Delegado de Policia supplente em exercicio Cidadaõ

15 Norberto de Goes Barretto, comigo escrivaõ de seu cargo, ahi compareceu Urbano Bispo de Missias, Inspector de quarteiraõ, dizendo que tinha effectuado a prizaõ de Anto-

20 nio José dos Santos, conhecido por Antonio Custodio, em acto de, com aguardente laborando em fôgo, queimar Angelina Maria da Cruz, na Caza d'elle declarante, a pretesto de

25 fazer-lhe uma Cura, e por isso o conduzia perante a dita autoridade acompanhado das testemunhas que rezidem no lugar e sabem do

Os inquéritos policiais editados e descritos referem-se a crimes relacionados a práticas populares de cura, apresentando um repertório lexical que revela o universo sociocultural, religioso e jurídico comum àqueles sujeitos no período de transição do Império para a República no Brasil. A esse respeito, Oliveira e Isquerdo (1998, p. 7) asseveram que

[...] o universo lexical de um grupo sintetiza a sua maneira de ver a realidade e a forma como seus membros estruturam o mundo que os rodeia e designam as diferentes esferas do conhecimento. Assim, na medida em que o léxico recorta realidades de mundo, define, também, fatos de cultura. Portanto, estudar o léxico de uma comunidade significa desvendar os mistérios de sua história, de sua cultura e de suas relações sociais em um determinado período do tempo.

A leitura dessas fontes documentais evidencia, assim, o panorama dos modos de vida, dos valores e padrões de comportamento, das subjetividades, das representações sociais, das relações de poder, do aparato jurídico da época e dos discursos relativos aos sujeitos referenciados. 


\section{O campo lexical do curandeirismo}

A partir das edições semidiplomáticas dos dois inquéritos policiais produzidos em Maruim/Sergipe, em 1889 e 1897, relativos a crimes motivados por práticas místico-religiosas de cura, procedeu-se ao levantamento das lexias pertencentes ao campo lexical do curandeirismo, entendido no período como crime contra a saúde pública, campo produtivo e representativo da temática abordada nos documentos.

Com a ajuda da ferramenta WordList do programa AntConc, desenvolvido por Laurence Anthony (2014), foram selecionados nos dois textos 144 itens lexicais e suas variantes, o que possibilitou, com base nas relações hierárquicas entre os lexemas, sua organização em três macrocampos: sujeitos que recebem a cura, enfermidades e práticas de cura, cada um dos quais se subdivide em microcampos e/ou subcampos mais específicos, como pode ser observado no quadro a seguir:

Quadro 2 - Organização das lexias do campo lexical do curandeirismo.

\begin{tabular}{|c|c|c|c|c|}
\hline 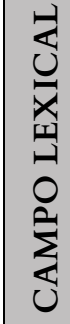 & 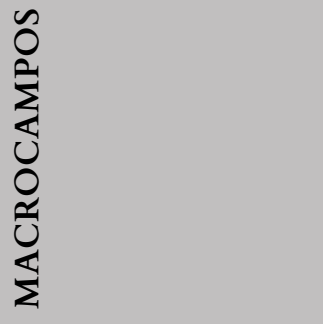 & 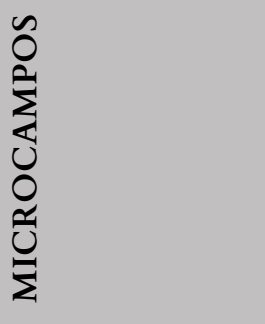 & 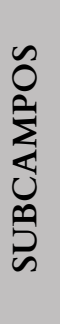 & 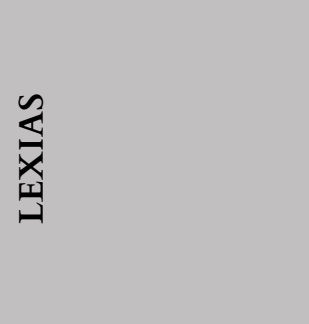 \\
\hline & $\begin{array}{c}\text { SUJEITOS QUE } \\
\text { RECEBEM A } \\
\text { CURA }\end{array}$ & & & $\begin{array}{c}\text { doente (6), enferma } \\
\text { (1), finado (3), } \\
\text { morto (1) }\end{array}$ \\
\hline & \multirow{3}{*}{ ENFERMIDADES } & & & $\begin{array}{c}\text { gastroentirite aguda } \\
\text { (1), asma (1), catarro } \\
\text { (1) }\end{array}$ \\
\hline & & CAUSAS & & $\begin{array}{c}\text { maleficio (4), } \\
\text { feitiçaria (1) }\end{array}$ \\
\hline & & SINTOMAS & & $\begin{array}{c}\text { adoentado (1), } \\
\text { fraqueza nas pernas } \\
\text { (1), attaques } \\
\text { asmaticos (1) }\end{array}$ \\
\hline & & NOMEAÇÃO & & cura (2) \\
\hline & & LOCAL & & casa (1) \\
\hline
\end{tabular}




\begin{tabular}{|c|c|c|c|}
\hline \multirow[t]{9}{*}{$\begin{array}{l}\text { PRÁTICAS DE } \\
\text { CURA }\end{array}$} & $\begin{array}{l}\text { PROCESSOS E } \\
\text { MÉTODOS }\end{array}$ & & $\begin{array}{c}\text { ministrar } \\
\text { substancias } \\
\text { venenozas (1), dar } \\
\text { remedios (1), } \\
\text { applicar remedio } \\
\text { (1), fazer cura (2), } \\
\text { fazer curativo (1), } \\
\text { curar (8), incendiar } \\
\text { (1), queimar (6), dar } \\
\text { talho (1), insopar } \\
\text { (1), deitar (1), } \\
\text { laborar em fôgo } \\
\text { (1), pôr fôgo (1), } \\
\text { apagar o fogo (1), } \\
\text { encostar (1), fazer } \\
\text { mezas (1), fazer } \\
\text { feitiçarias (1), tomar } \\
\text { garrafas (1) }\end{array}$ \\
\hline & \multirow[t]{2}{*}{ MATERIAIS } & ORGÂNICOS & $\begin{array}{c}\text { capuxos de algudaõ } \\
(1), \text { algudaõ (3) }\end{array}$ \\
\hline & & NÃO ORGÂNICOS & chicara (2) \\
\hline & \multirow{3}{*}{ SUBSTÂNCIAS } & SÓLIDAS & $\begin{array}{c}\text { casca de jurema (1), } \\
\text { alho (1), fumo (1) }\end{array}$ \\
\hline & & LÍQUIDAS & $\begin{array}{c}\text { poçaõ (1), } \\
\text { aguardente (6), } \\
\text { beberajem (4), } \\
\text { garrafa [de } \\
\text { beberajem] (7), } \\
\text { agua (1) }\end{array}$ \\
\hline & & GENÉRICAS & $\begin{array}{c}\text { tóxicas (1), } \\
\text { venenozas (1), } \\
\text { remedio (7), veneno } \\
(1), \text { corroziva (1) }\end{array}$ \\
\hline & \multirow{2}{*}{ QUANTIDADE } & $\begin{array}{c}\text { VALOR } \\
\text { DETERMINADO }\end{array}$ & posta (1), molhos (1) \\
\hline & & $\begin{array}{c}\text { VALOR } \\
\text { INDETERMINADO }\end{array}$ & $\begin{array}{l}\text { poco (1), muita (1), } \\
\text { bastante (1), grande } \\
\text { quantidade (1) }\end{array}$ \\
\hline & DIMENSÃO & & $\begin{array}{l}\text { proporção de } \\
\text { ventoza (1), } \\
\text { pequeno (2) }\end{array}$ \\
\hline
\end{tabular}




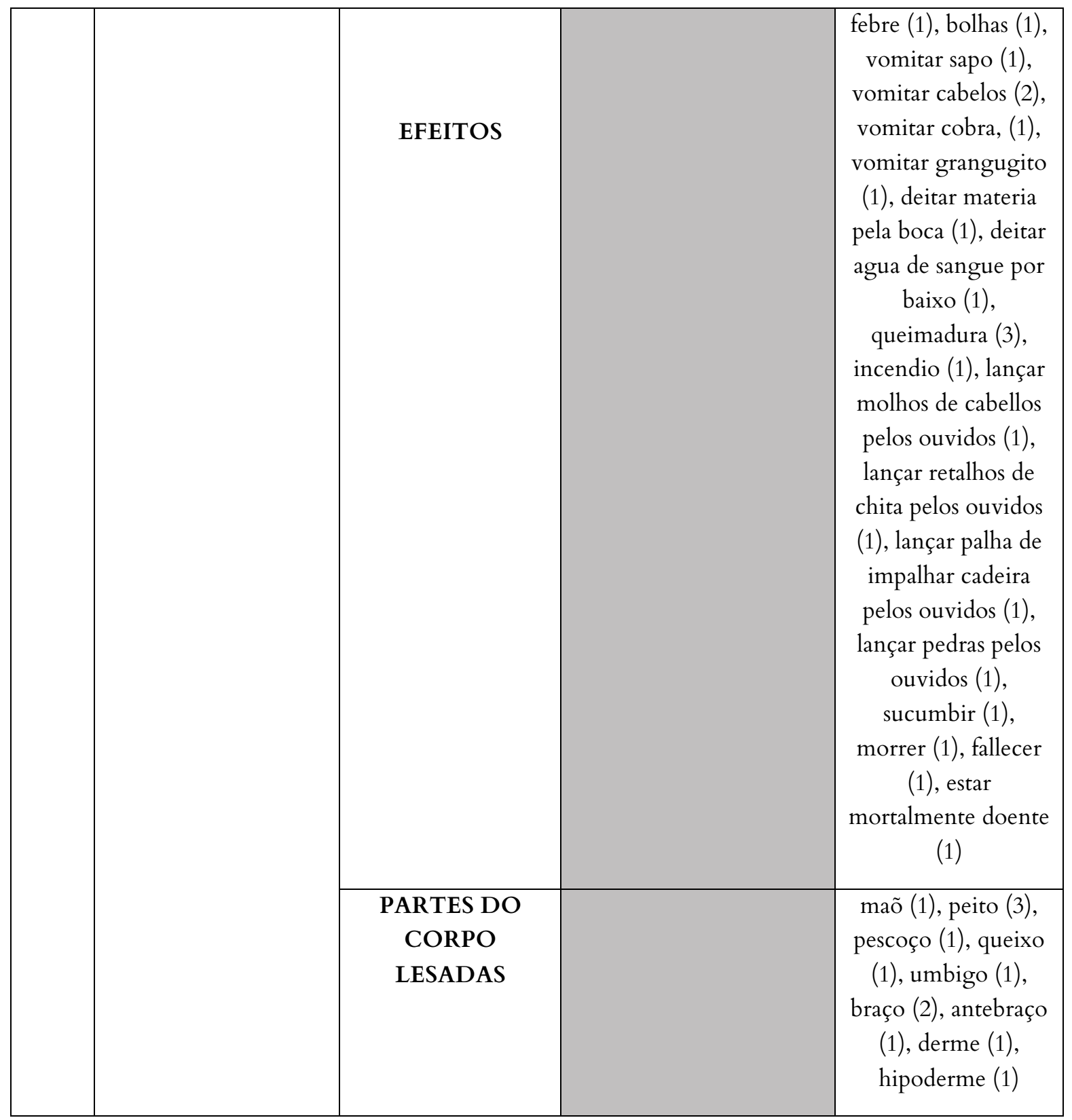

Fonte: Elaboração própria.

Com essa estruturação, que representa uma pequena parcela do vocabulário do curandeirismo usado em dois registros judiciais do final do século XIX, é possível ter uma ideia de como as práticas de cura aconteciam na época, os materiais e substâncias utilizadas e as doenças que motivaram a procura dos curandeiros.

Contudo, é importante destacar que, apesar desses inquéritos abordarem crimes motivados pelo curandeirismo, o gênero discursivo em questão pertence à esfera jurídica, o que justifica que grande parte do seu repertório lexical se refira exclusivamente ao discurso jurídico-penal. Dessa forma, por exemplo, o léxico que identifica os sujeitos que praticam as curas - accuzado, delinquente, individuo, respondente, declarante -, o sujeito que recebe a cura - offendida - ou a nomeação das práticas de cura - 
crime de ofenças fizicas, delicto, facto crimonoso, facto delictoozo - é comum a outros textos do mesmo domínio discursivo.

Ademais, reconhece-se que muitas outras lexias sistematizadas no Quadro 2 não são exclusivas do curandeirismo. A prática em si, pertencente ao macrocampo "Práticas de Cura", está melhor representada nos microcampos "Processos e métodos", "Substâncias", especialmente as líquidas, e "Efeitos".

A seguir, faz-se a descrição dos campos lexicais do curandeirismo, baseada no modelo formulado por Celina Abbade (2004) para o campo da culinária portuguesa medieval. Depois de uma descrição de cada campo, atentando-se para a frequência das lexias, seguem exemplos de lexemas ${ }^{3}$, acompanhados de suas informações semânticas, de acordo com dicionários vernaculares ${ }^{4}$ e técnicos ${ }^{5}$ do século XIX, e dos contextos em que aparecem no corpus $^{6}$.

No que diz respeito ao macrocampo das enfermidades das pessoas que procuraram o curandeirismo, há onze lexias distribuídas em dois microcampos - causas e sintomas. Chama a atenção que o lexema catarro, que seria mais adequado ao campo dos sintomas, aparece no texto como um tipo de doença. Além disso, um dado interessante é a busca das pessoas pela cura de enfermidades causadas por feitiço, como pode ser observado nos lexemas maleficio e feitiçaria, no microcampo das causas. Esse é o universo do imaginário popular, das superstições, da crença em fenômenos sobrenaturais.

Exemplo:

[malefício] s.m. (4) maleficio (2) malificio (2). O mal feito a alguém. Feitiço.

(3) Que soffrendo, seu o finado Antonio, de uma fraqueza nas pernas, alguem na rua do Rozario disse-lhe que elle soffria de maleficio ... (Inquérito Policial de 1889, f. 3v, 1. 65)

Cento e quinze itens lexicais estão dispostos no macrocampo das práticas de cura, o mais produtivo, que se divide nos seguintes microcampos:

\footnotetext{
${ }^{3}$ Estrutura: lema (entrada com letras minúsculas em negrito e forma ortográfica moderna; caso a forma usual hoje não tenha registro no corpus, a entrada recebe colchetes); classificação gramatical; número de ocorrências entre parênteses; variantes ortográficas; definiç̧ão.

${ }^{4}$ Diccionario da Lingua Portugueza, de Antonio de Moraes Silva (1813), e Diccionario da lingua brasileira, de Luís Maria da Silva Pinto (1832).

${ }^{5}$ Diccionario de medicina popular, de Pedro Luiz Napoleão Chernoviz (1890).

${ }^{6}$ Entre parênteses está o ano do documento, seguido do fólio e da linha da ocorrência da lexia.
} 
- Nomeação: relativo ao modo como a prática da cura era designada nos inquéritos;

- Local: espaço onde houve o procedimento da cura;

- Processos e métodos: demonstra os processos e os modos de fazer a cura;

- Materiais: instrumentos utilizados na cura;

- Substâncias: elementos utilizados na cura;

- Quantidade: grandeza de valor dos materiais ou substâncias utilizados na cura;

- Dimensão: tamanho de elemento expelido ou de corte feito no corpo da vítima;

- Efeitos: os resultados das ações praticadas;

- Partes do corpo lesadas: indica a parte do corpo da vítima que foi prejudicada pela ação praticada.

Nesse macrocampo, observa-se o uso que os curandeiros faziam de elementos da natureza e de objetos ordinários, como água, alho, fumo, casca de jurema (árvore), aguardente, algodão, xícara.

Em processos e métodos, a lexia curar é a mais frequente, aparecendo oito vezes, resultado que, fora de contexto, pode indicar o reconhecimento da intenção de fornecer a cura ao enfermo, ou do curandeirismo como mais uma forma terapêutica legítima. No entanto, nos casos relatados nos inquéritos, essa lexia é por três vezes acompanhada pela expressão a pretexto de/ sob pretexto de, que fornece a dimensão da indiferença a essa atividade terapêutica popular.

Há que se notar também que as tentativas de cura descritas nos documentos não foram bemsucedidas, seja pela manipulação equivocada dos materiais ou do nível de toxidade dos elementos utilizados, agravando ainda mais o estado de saúde ou levando à morte pessoas que buscaram formas alternativas de tratamento. Assim, no microcampo efeitos, estão dispostas as lexias que representam os resultados das ações praticadas, chamando atenção vomitar e lançar, que se conjugam com uma série de outros termos que indicam a associação do curandeirismo com o sobrenatural.

Exemplos: 
[beberagem] s.f. (4) beberajem (3) beberajens (1). Bebida que os curandeiros dão como medicamento. O mesmo que garrafada.

(4) ... seu filho passando a fazer uzo de dita beberajem deu logo em vomitar ... (Inquérito Policial de 1889, f. 4r, 1. 69)

[capulho] s.m. (1) capuxos (1). A casca do botão da flor. Também se diz do algodão.

(5) ... a aguardente queimando em dous capuxos de algudão, ... (Inquérito Policial de 1897, f. 3v, 1. 57)

jurema s.f. (1). Gênero de árvores da família das leguminosas, também conhecida como mimosa hostilis ou acacia jurema. Planta usada para fins medicinais. Sua casca é adstringente, empregada em banhos contra inchaços. Beberagem enfeitiçada.

(6) ... contendo aguardente do reino, casca de jurema, alho e muito fumo ... (Inquérito Policial de 1889, f. 5r, 1. 95)

O estudo lexical proposto neste trabalho, fundamentado na teoria dos campos lexicais coseriana, reconhece as lexias como unidades portadoras de valor semântico em relação com um contexto extralinguístico. Desta forma, propõe-se uma representação gráfica das relações semânticas existentes entre as lexias do campo lexical do curandeirismo, através de um mapa conceitual produzido com o suporte do programa Mindomo?:

\footnotetext{
${ }^{7}$ Disponível em: https://www.mindomo.com.
} 
Figura 3 - Mapa conceitual do campo lexical do curandeirismo.

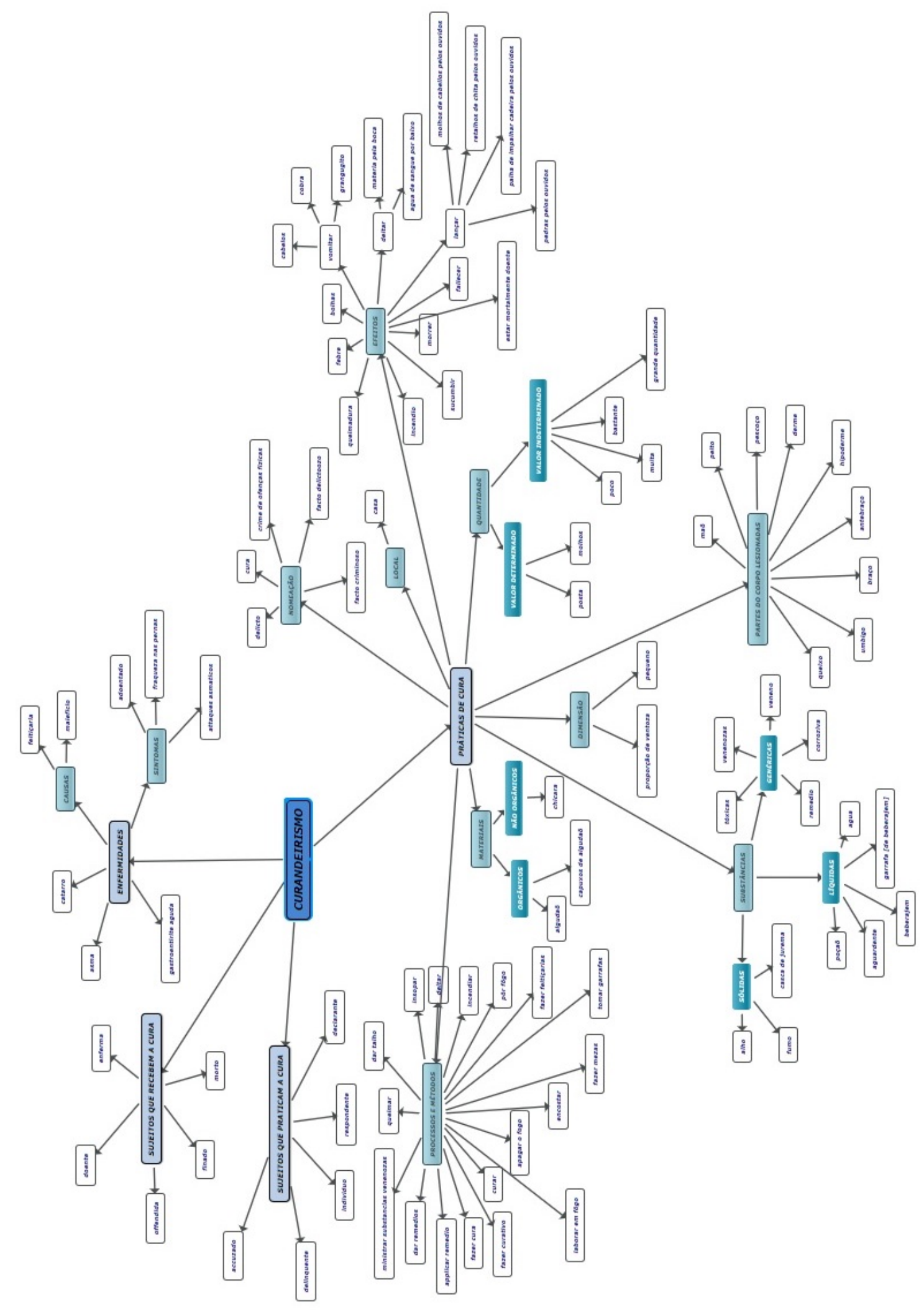

Fonte: Elaboração própria. 
A organização das lexias selecionadas em campos lexicais permitiu entender um pouco do universo das práticas e saberes místico-religiosos de cura, que, embora tradicionais, acabaram por encontrar resistência nos discursos médico e jurídico, os quais, contrários a qualquer tipo de atividade terapêutica que não fosse a oficial, acabaram por criminalizar o curandeirismo, fundamentando, assim, relações de poder.

Embora as palavras não revelem explicitamente a repressão e a condenação penal aos curandeiros pelo exercício ilegal da medicina, mas pelo fato de, no lugar da cura, terem atentado contra a vida de outras pessoas, enquadrando-os nos crimes de lesão corporal e homicídio, as categorias atribuídas às suas práticas as identificam negativamente.

O conceito de curandeirismo gerado no campo jurídico e reproduzido nos documentos analisados encontra-se no macrocampo das práticas de cura, especialmente nos microcampos das substâncias, dos processos e métodos e, em certa medida, dos efeitos. Assim, os limites entre as práticas curativas médico-científicas e as místico-religiosas estava no que era utilizado, de que forma e com que resultados.

\section{Considerações finais}

A estruturação do campo lexical do curandeirismo, que agrupa as lexias presentes nos inquéritos policiais editados, representativas das práticas e saberes populares de cura, possibilitou uma reflexão sobre uma parcela da história cultural brasileira do século XIX, ajudando a entender a criminalização de atividades terapêuticas que recorriam a elementos da natureza e a forças ocultas. Para tanto, foi essencial o diálogo entre diferentes áreas do conhecimento, como a Filologia, a Lexicologia e a História, que possuem em comum a relação de seus objetos de estudo com a cultura.

Os documentos analisados, importantes como fontes para o esclarecimento do tema, revelam aspectos de práticas curativas místico-religiosas, como seus métodos, seus saberes e sua inserção em diferentes grupos sociais, identificadas de maneira negativa como feitiçaria e que, por isso, não são legitimadas pela classe dominante e pelos instrumentos e agentes judiciais, mas encontram o respaldo das classes populares.

Assim, o repertório lexical inventariado representa os conflitos existentes entre dois discursos opostos que circulavam no período: o discurso legal, influenciado pela ideologia higienista, amparado em conhecimentos científicos para o avanço da sociedade, e o discurso dos curandeiros e das pessoas que acreditavam na cura pela fé, baseado em saberes ancestrais de um povo que ainda hoje segue lutando para manter viva sua tradição. 
O trabalho realizado configura-se como contribuição para os estudos lexemáticos no Brasil e para o conhecimento de um aspecto da sociedade sergipana e brasileira do final dos oitocentos. 


\section{Referências bibliográficas}

ABBADE, Celina Márcia de Souza. Os campos lexicais do Livro de Cozinha da Infanta D. Maria. Anais da XX Jornada Nacional de Estudos Linguísticos - GELNE. João Pessoa, PB: Ideia, 2004, p. 437-444.

ABBADE, Celina Márcia de Souza. Lexicologia social: a lexemática e a teoria dos campos lexicais. In: ISQUERDO, Aparecida Negri; SEABRA, Maria Cândida Trindade Costa de (Orgs.). As ciências do léxico: lexicologia, lexicografia, terminologia. Vol. VI. Campo Grande, MS: Ed. UFMS, 2012. p. 140-161.

ALMEIDA, Diadney Helena de. Um estudo das interações culturais entre curandeiros e médicos acadêmicos no Rio de Janeiro Oitocentista. XIII Encontro de História Anpuh-Rio, p. 1-10, 2008.

ANTHONY, Laurence. AntConc. Versão 3.4.4w. Japan: Waseda University, 2014.

ARQUIVO GERAL DO JUDICIÁRIO (Ed.). MARC/C. $2^{\circ}$ OF - Inquérito Policial, Cx. 01/1014.

ARQUIVO GERAL DO JUDICIÁRIO (Ed.). MAR/C. $2^{\circ}$ OF - Inquérito Policial, Cx. 01/1833.

BENVENISTE, Emile. Problemas de Linguística Geral I. 3. ed. São Paulo: Pontes, 1991.

BIDERMAN, Maria Tereza Camargo. Fundamentos da Lexicologia. Teoria Lingüística: lingüística quantitativa e computacional. Rio de Janeiro: Livros Técnicos e Científicos, 1978, p. 71-166.

BURKE, Peter. Linguagens e comunidades nos primórdios da Europa Moderna. Trad. Cristina Yamagami. São Paulo: Editora UNESP, 2010.

CÂMARA JR., Joaquim Mattoso. Língua e cultura. Transcrito da Revista Letras, p. 51-59, 1955. Disponível em: https://revistas.ufpr.br/letras/article/view/20046/13227. Acesso em: 20 maio 2020.

CAMBRAIA, César Nardelli; MEGALE, Heitor. Filologia Portuguesa no Brasil. D.E.L.T.A., Vol. 15, No Especial, 1999.

CHERNOVIZ, Pedro Luiz Napoleão. Diccionario de medicina popular e das sciencias accessorios para uso das familias, contendo a descripção das Causas, symptomas e tratamento das moléstias; as receitas para cada molestia; As plantas medicinaes e as alimenticias; As aguas mineraes do Brazil, de Portugal e de outros paizes; e muitos conhecimentos uteis. 6. ed. Paris: A Roger \& F Chernoviz, 1890. 2 v. Disponível em: https://www.bbm.usp.br/pt-br/dicionarios/diccionario-de-medicina-popular-e-das-scienciasaccessórias-para-uso-das-familias/. Acesso em: 13 jul. 2019.

COSERIU, Eugenio. Principios de Semántica Estructural. Madrid: Gredos, 1977. 
COSERIU, Eugenio. Gramática, semántica, universales estudios de la lingüística funcional. 2. ed. rev. Madrid: Gredos, 1987.

COSTA, Maria. Influências do discurso médico e do higienismo no ordenamento urbano. Revista da ANPEGE, v. 9, n. 11, p. 63-73, jan./jun. 2013.

DURANTI, Alessandro. Antropología Lingüística. Trad. Pedro Tena. Madrid: Cambridge University Press, 2000.

ELIAS, Norbert. O processo civilizador: Uma história dos costumes. V.I. Rio de Janeiro: Jorge Zahar Ed., 1994.

FACHIN, Phablo Roberto Marchis. Descaminhos e dificuldades: leitura de manuscritos do século XVIII. Goiânia: FAPESP, 2008.

FARIA, Marcelo. Destruindo a farsa do "não temos provas (sobre Lula), mas temos convicção. Ilisp, 15 set. 2016. Disponível em: http://www.ilisp.org/artigos/destruindo-farsa-do-nao-temosprovas-sobre-lula-mas-temos-conviccao/. Acesso em: 25 maio 2020.

GRINBERG, Keila. A História nos porões dos arquivos judiciários. In: PINSKY, Carla Bassanezi; LUCA, Tania Regina de (Orgs.). O historiador e suas fontes. São Paulo: Contexto, 2009. p. 119-139.

GONDRA, José Gonçalves. Artes de civilizar: medicina, higiene e educação escolar na Corte Imperial. Rio de Janeiro: Ed. UERJ, 2004.

HAVELOCK, Eric A. A revolução da escrita na Grécia e suas consequências culturais. Trad. Ordep José Serra. São Paulo: Editora da Universidade Paulista; Rio de Janeiro: Paz e Terra, 1996.

JACÓ-VILELA, Ana Maria et al. Os estudos médicos no Brasil no século XIX: contribuições à Psicologia. Memorandum, 7, p. 138-150, 2004. Disponível em:

http://www.fafich.ufmg.br/ memorandum/artigos07/artigo09.pdf. Acesso em: 18 maio 2020.

KATO, Mary A. Como, o que e por que escavar? In: ROBERTS, Ian; KATO, Mary A. (Orgs.).

Português Brasileiro: uma viagem diacrônica: homenagem a Fernando Tarallo. 2 ed. Campinas, SP: Editora da UNICAMP, 1996, p. 13-27.

LINS, Ivan. História do Positivismo no Brasil. São Paulo: Companhia Editora Nacional, 1964.

MANSANERA, Adriano Rodrigues; SILVA, Lúcia Cecília da. A influência das idéias higienistas no desenvolvimento da psicologia no Brasil. Psicologia em Estudo, v. 5., n. 1, p. 115-137, 2000.

MARCOTULIO, Leonardo Lennertz et al. Filologia, história e língua: olhares sobre o português medieval. São Paulo: Parábola, 2018.

MATTOS E SILVA, Rosa Virgínia. Para a História do Português Culto e Popular Brasileiro: sugestões para uma pauta de pesquisa. In: ALKMIM, Tania Maria (Org.). Para a História do Português Brasileiro. Vol. III: Novos Estudos. São Paulo: Humanitas/FFLCH/USP, 2002, p. 443-464. 
MEGALE, Heitor; TOLEDO NETO, Sílvio de Almeida (Orgs.). Por minha letra e sinal: documentos do ouro do século XVII. Cotia, SP: Ateliê Editorial, 2005.

MORAES SILVA, Antonio de. Diccionario da Lingua Portugueza. Lisboa: Lacérdina, 1813. Disponível em: http://200.144.255.59/catalogo_eletronico/consultaDocumentos.asp?Tipo_Consulta=Acervo\&A cervo_Codigo=2\&Setor_Codigo=11. Acesso em: 13 jul. 2019.

OLIVEIRA, Ana Maria Pinto Pires, ISQUERDO, Aparecida Negri. (Orgs.). As ciências do léxico: lexicologia, lexicografia, terminologia. Campo Grande, MS: Ed. UFMS, 1998.

PASSOS, Márcia Maria Barros dos et al. A disseminação cultural das garrafadas no Brasil: um paralelo entre medicina popular e legislação sanitária. Saúde Debate. Rio de Janeiro, v. 42, n. 116, p. 248-262, jan./mar. 2018.

PINTO, Luís Maria da Silva. Diccionario da lingua brasileira. Ouro Preto: Typographia de Silva, 1832. Disponível em: https:/www.bbm.usp.br/pt-br/dicionarios/diccionario-da-linguabrasileiral. Acesso em: 13 jul. 2019.

PUTTINI, Rodolfo Franco. Curandeirismo, curandeirices, práticas e saberes terapêuticos: reflexões sobre o poder médico no Brasil. Revista de Direito Sanitário, São Paulo, v. 11, n. 3, p. 32-49, nov. 2010/fev. 2011.

ROMANO, Rogério Tadeu. Do inquérito policial e da investigação criminal promovida pelo Ministério Público, s/d. Disponível em: https://www.jfrn.jus.br/institucional/bibliotecaold/doutrina/Doutrina265-do-inquerito-policial.pdf. Acesso em: 20 maio 2020.

SANTOS, Edmar Ferreira. O poder dos candomblés: perseguição e resistência no Recôncavo da Bahia. Salvador: EDUFBA, 2009.

SEABRA, Maria Cândida Trindade Costa de. Língua, cultura, léxico. In: SOBRAL, Gilberto Nazareno Telles; LOPES, Norma da Silva; RAMOS, Jânia Martins (Orgs.). Linguagem, sociedade e discurso. São Paulo: Blucher, 2015. p. 65-84.

SILVA, Eugênia Andrade Vieira da. Guia de fontes temáticas. Aracaju: Tribunal de Justiça, 2009. SOUZA, Laura de Mello e. O diabo e a terra de Santa Cruz: feitiçaria e religiosidade no Brasil Colonial. 2. ed. São Paulo: Companhia das Letras, 2009.

TEIXEIRA, Maria da Conceição Reis. Representação do sertão baiano em Seara Vermelha, de Jorge Amado: o campo lexical dos trabalhadores. In: FARGETTI, Cristina Martins; MURAKAWA, Clotilde Almeida Azevedo; NADIN, Odair Luiz (Orgs.). Léxico e cultura. Araraquara, SP: Letraria, 2015. p. 65-71.

ULLMANN, Stephen. Semântica: uma introdução à ciência do significado. Trad. José Alberto Osorio Mateus. 4. ed. Lisboa: Fundação Calouste Gulbenkian, 1964. 